\title{
PRIVACY, FACE, AND SOCIAL RESPECTABILITY IN A DIGITAL CHINA
}

\author{
Ariane Ollier-Malaterre \\ University of Quebec in Montreal
}

\section{Introduction}

This study is an exploratory analysis where I focus on understanding what Chinese citizens consider as "private" when they use social media, shop online, and make other electronic payments using WeChatPay and AliPay. Western scholarship defines privacy as the right of individuals, groups, or institutions to decide what information about themselves to communicate to others, and when and how to do so (Westin, 1967). Simply put, privacy pertains to "what people conceal and reveal and what others acquire and ignore" (Anthony, Campos-Castillo, \& Horne 2017: 251). In the context of social media and e-commerce platforms, privacy is increasingly viewed as "networked" (Wu, Vitak, \& Zimmer, 2019), i.e., a collaboration with others within a social context. While people in many countries grapple with the opaque privacy implications of the internet and social media, the case of China is particularly interesting because people leave a wealth of digital traces every day, as they use all-encompassing platforms and pay almost everything electronically, and because these data are being collected and mined by companies and the government (Creemers, 2017).

\section{Study Methods}

This study is part of a larger project (a book in progress) on perceptions of privacy, governance, and surveillance in China, in light of Chinese history, socio-economic context, and political system. I conducted 58 semi-structured in-depth interviews in 2019 in Beijing, Shanghai, and Chengdu, and took diary notes on my observations as I traveled in Western China and Sichuan. The 58 interviews comprise 44 formal interviews with men and women recruited in collaboration with Chinese professors and 14 in-depth conversations with key informants (all Chinese except 3 who had been living in China for a long time). The sample was contrasted in terms of gender, age, education level, and industry sector (public sector/state-owned company/private company/multinational). Half of the interviews took place in English and half in Mandarin, at a location of the interviewee's choice; I was accompanied by a Chinese interpreter for most of the formal interviews, which also served to alleviate interviewees' potential concerns about my "waiguoren", i.e., foreigner identity. I started with descriptive questions on the participant's use of WeChat and the internet and moved 
gradually to questions on privacy and surveillance. My approach is constructivist; I fully acknowledge that my country affiliation contributes to shaping what Chinese people share with me, with both benefits and drawbacks. I analyzed the interviews and diary notes using inductive content analysis methods.

\section{Findings \& Discussion}

Privacy is written with two different words in Mandarin: yǐnsī (a personal thing you do not wish to disclose in public) and yīnsī (hiding a shameful secret) (Cao, 2005). My interviewees clearly used the latter meaning, viewing privacy as face-saving, that is controlling the exposure of shameful information and feelings to social groups that could judge them negatively, to maintain moral and social respectability. Face comprises two concepts in Chinese thought: lien refers to moral character integrity, whereas mien-tzi refers to reputation in terms of success in life. Lien has been translated as moral face, and mien-tzi as social face. Lien is independent of social status, whereas mien-tzi depends on power and prestige. To lose lien is "a condemnation by the group for immoral or socially disagreeable behavior".

Considering face as lien, shameful things include the behaviors, thoughts, and emotions that can be judged negatively by others. Interviewees mentioned "shameful things" such as personal medicine, underwear and sex-related products, and socially questionable purchases such as weapons.

Considering face as mien-tzi, shame is induced by low-status markers such as low-level jobs, which denote poor success, as well as high-status markers because the latter may embarrass others who are less successful. The higher the social standing, the more one has to deal with people of lesser status in dignified ways. Financial information is what interviewees most often considered private, particularly well-off interviewees, because that information may embarrass others who do less well.

Moreover, my interviewees perceived the need to hide shameful information only from interlocutors who could make them lose face: parents and supervisors, or hackers who would disclose personal information, but not an abstract entity such as the government. For instance, several interviewees felt they could hide on Weibo, using a pseudonym. Although Weibo, like Twitter, is a large public social network, they described it as a space where they could "escape" and "be themselves", unlike WeChat group chats and "Moments" (the equivalent of Facebook's wall) where they felt watched by individuals and groups that mattered for their reputation. The fact that Weibo requires users' real names upon registration was not raised as a privacy concern because it does not relate to reputation (it does, however, imply that the company and the government may identify the authors of posts and comments, which many Western citizens would frame as a privacy concern).

Elders and supervisors were the figures from which it was most important to hide shameful information. They were given "safe news". Health, financial, employment or marriage issues were concealed to prevent parents from worrying and avoid parental interference. For instance, a colleague with severe hypertension invited me to dinner at his home; he said nothing when his mother salted the dishes heavily, and later explained she did not know about his condition. Likewise, Ph.D. candidates in a lab I visited hid their social media WeRun profiles from their supervisors so that the supervisors did not know how much time they spent running instead of studying. These findings on privacy may help to shed slight on how Chinese citizens view the digitalization of surveillance through facial recognition monitoring and the building of the 
social credit system (Liang, Das, Kostyuk, \& Hussain, 2018), and on what legal basis they may assert their rights (e.g., reputation vs. privacy rights; Cao, 2005). Importantly, moving beyond Western definitions of privacy to understand the concept's multi-faceted nature may guide future context-sensitive research on privacy and surveillance.

\section{References}

Anthony, D., C. Campos-Castillo, \& C. Horne. (2017). Toward a Sociology of Privacy. Annual Review of Sociology, 43: 249-269.

Cao, J. (2005). Protecting the Right to Privacy in China. Victoria University of Wellington Law Review 25: 645.

Cheng, C.Y. (1986) The concept of face and its Confucian roots. Journal of Chinese Philosophy, 13: 329-348.

Creemers, R. (2017) Cyber China: Upgrading Propaganda, Public Opinion Work and Social Management for the Twenty-First Century. Journal of Contemporary China, 26: 85-100.

Hwang. K.K. \& Han, K.H. (2010) Face and morality in Confucian society. In: Bond, M. H. (ed) The Handbook of Chinese Psychology. London: Oxford University Press, 479498.

Hu, H.C. (1994) The Chinese Concepts of "Face". American Anthropologist, New Series, 46: 45-64.

Liang, F., Das, V., Kostyuk, N., \& Hussain, M. M. (2018). Constructing a Data-Driven Society: China's Social Credit System as a State Surveillance Infrastructure. Policy \& Internet, 10(4), 415-453.

Westin, A. F. (1967). Privacy and Freedom. London: The Bodley Head Ltd.

Wu, P. F., Vitak, J., \& Zimmer, M. T. (2019). A contextual approach to information privacy research. Journal of the Association for Information Science and Technology, 71(4), 485-490. 